\title{
THE USE OF DIATOMS FOR PALEOHYDROLOGICAL AND PALEOENVIRONMENTAL RECONSTRUCTIONS OF ITUPANEMA BEACH, PARÁ STATE, AMAZON REGION, DURING THE LAST MILLENNIUM
}

\author{
FÁBIO CAMPOS PAMPLONA RIBEIRO, CRISTINA DO SOCORRO FERNANDES DE SENNA \\ LAPPAM, CCTE, Museu Paraense Emílio Goeldi, Cx. Postal 399, 66040-170, Belém, PA. \\ fbpamplona@yahoo.com.br, csenna@museu-goeldi.br \\ LEZILDACARVALHO TORGAN \\ MCN, FZBRS, Av. Dr. Salvador França, 1427, 90690-000, Porto Alegre-RS. torgan@ cpovo.net
}

\begin{abstract}
Five sedimentary cores were collected on the ancient sedimentary clay deposits of Itupanema Beach, Barcarena town, Pará State, Amazon region, where diatom analysis was performed to infer the history of the paleoecological and paleohydrological changes during the last millennium. The results revealed 58 diatoms species among benthic and planktonic life forms. Correspondence analysis applied to relative abundance of diatoms and associated with sedimentary texture, OM contents and ${ }^{14} \mathrm{C}$ dating, defined three ecozones. The lower sandy ecozone 1 dated at $930 \pm 40{ }^{14} \mathrm{C}$ yr BP $(\mathrm{Beta}$ 217590) was dominated by the benthic/epipsammic species Staurosira obtusa, Staurosirella pinnata and Staurosirella crassa (nov. comb.), that indicated more hydrodynamic energy than in present days, originating a shallow sedimentary environment, under erosive conditions, unfavorable to the colonization of vegetation. The intermediate grey clay ecozone 2 that was observed only in the IT1 core, dated at $520 \pm 40{ }^{14} \mathrm{C}$ yr BP (Beta 217591) showed the prevalence of planktonic diatoms, providing evidence of a deeper and calmer environment, located in a probably protected area, with intense sedimentation of clay particles with abundant plant remains, colonized by mangrove forest and alluvial palm forest. The upper organic-clay to organic-sand ecozone 3 much younger than $520 \pm 40{ }^{14} \mathrm{C} \mathrm{yr} \mathrm{BP}$, showed more agitated and erosive sedimentary conditions, however, with less energy than that in lower ecozones, indicated by higher abundance of $A$. granulata, strongly silicified. This new sedimentary environment allowed colonization by aquatic macrophyte vegetation which persists on the beach today.
\end{abstract}

Key words: diatoms, taxonomy, tidal plain, estuaries, Amazon, Brazil.

RESUMO - A análise de diatomáceas realizada em cinco testemunhos sedimentares obtidos de um antigo depósito sedimentar na praia de Itupanema, Barcarena, Estado do Pará, região amazônica, permitiu inferir a história das mudanças paleoecológicas e palaeohidrológicas durante o último milênio. Os resultados revelaram a presença de 58 espécies de diatomáceas, de hábitos bentônico e planctônico. A Análise de Correspondência foi aplicada aos dados de abundância relativa de diatomáceas e associada à textura sedimentar, teor de $\mathrm{MO}$ e datações ${ }^{14} \mathrm{C}$, definindo três ecozonas. As ecozonas inferiores 1, datadas em $930 \pm 40{ }^{14} \mathrm{C}$ anos AP (Beta 217590), mostraram dominância de Staurosira obtusa, Staurosirella pinnata e Staurosirella crassa (comb. nov.), bentônicas/epipsâmicas, que indicaram maior energia hidrodinâmica que os dias atuais, em um ambiente sedimentar arenoso raso, erosivo, desfavorável para a colonização da vegetação. Na ecozona intermediária 2, com sedimentos argilo-orgânicos cinza e abundantes restos vegetais, observados somente em IT1, datados em $520 \pm 40{ }^{14} \mathrm{C}$ anos AP (Beta 217591), dominaram as diatomáceas planctônicas em um ambiente mais profundo e mais calmo, localizado em uma provável área protegida, colonizada por manguezal e floresta aluvial. As ecozonas superiores 3 , argilo-orgânicas a areno-orgânicas, mostraram o retorno de um ambiente mais agitado e erosivo, porém, com menor energia do que nas ecozonas inferiores, provavelmente muito depois de $520 \pm 40{ }^{14} \mathrm{C}$ anos $\mathrm{AP}$, tendo em vista a maior abundância de A. granulata, fortemente silicificada. Este novo ambiente sedimentar permitiu a colonização da vegetação de macrófitas aquáticas que são observadas na praia até hoje.

Palavras-chave: diatomáceas, taxonomia, planície de maré, estuários, Amazônia, Brasil.

\section{INTRODUCTION}

Diatoms are an important component of the microphytobenthic community of intertidal sand flats of estuarine ecosystems and contribute markedly to primary production in plankton and play an important role within food webs (Pinckney \& Zingmark, 1993 in Kasin \& Mukai, 2006). These organisms are conserved in sediment, when subjected to anoxic conditions, because of the siliceous composition of their frustules (Cooper, 1999).

The estuaries are dynamic because they display high variability in the environmental variables such as salinity, 
sedimentary deposition processes, currents, turbidity and sediment biogeochemistry (Cooper, 1999). The estuarine processes form several depositional environments: (i) tidal flats, (ii) sand flats, (iii) mangroves, (iv) tidal channel bars, (v) beaches and (vi) dunes, observed in the Amazonian coastal zone (Souza Filho \& El-Robrini, 1996; França et al., 2007).

Sand flats show water's vertical movement generated by tides and other associated processes that promote the deposition and resuspension of sediment and affect the composition and distribution of the diatoms. In addition, hydrodynamic processes carry planktonic diatoms present in the aquatic estuarine environment to the intertidal zone (Mitbavkar \& Anil, 2002).

Thus, environmental changes affect the composition, diversity and abundance of the taxa, and therefore, diatom assemblages are excellent natural records of biostratigraphic modifications in temporal sedimentary series.

In Brazil, studies have utilized diatoms as useful biomarkers of paleoenvironmental reconstructions (Abreu et al., 1987; Ireland, 1987; Callegaro \& Lobo, 1990) and these studies have been intensified in the last decade, especially applied to the Brazilian Coastal Plain (Medeanic et al., 2001; Nascimento et al., 2003; Clerot et al., 2003; Saupe \& Mosimann, 2003; Medeanic \& Torgan, 2006; Medeanic et al., 2009). These papers were compared in terms of methodology and results when applied to the Holocene Brazilian Coastal Plain (Ribeiro \& Senna, 2005).

Papers are still scarce on the Amazonian North Coast of Brazil. Ribeiro et al. (2005) identified five ecozones based on diatom assemblage and related the different compositions to paleoenvironmental and paleohydrological changes, caused by relative variations in sea level, whose basal sediments were dated at $6850 \pm 40 \mathrm{yr}{ }^{14} \mathrm{C} \mathrm{BP}$ (Ribeiro et al., 2006). The diatom data were correlated to pollen data in the same core and showed the same paleoenvironmental and climatic events during the Holocene for Marapanim Bay, in Pará State (Senna \& Ribeiro, 2005).

A study of the modern diatom distribution in surface sediments, in the intertidal zone of Itupanema Beach, showed that the sand/clay ratio was influenced by present-day hydrodynamic processes, probably determining the local prevalence of planktonic diatom assemblages associated with muddy to mud-sandy sediments and benthic/epipsammic diatom assemblages associated with sandy samples (Ribeiro et al., 2008). These results allowed us to evaluate the whole of diatoms on estuarine dynamics as a biological indicator for erosion/accretion processes (Ribeiro et al., 2008).

Thus, the aim of the present paper was to determine whether the same modern pattern of diatom distribution occurred during the last millennium at Itupanema Beach, Amazon in Pará State, to infer the history of the paleoecological and paleohydrological changes along the sedimentary core sequences in ancient sedimentary deposits.

\section{STUDY AREA}

Itupanema Beach is located in Barcarena County (Figure 1) and integrates the continental estuarine sector of the coastal plain of Pará State (Alves et al., 2005). This area consists of sandy beaches that are small and narrow, and are always limited by promontories that originated during the Holocene, being influenced by both Guajará Bay and the estuary of the Pará River (Rodrigues, 1996 apud Oliveira, 2002).

The climate is characterized by a mean annual precipitation $>2000 \mathrm{~mm} \mathrm{yr}^{-1}$, classified as fully humid equatorial climate (IDESP, 1983 apud Oliveira, 2002). The seasonal regime of precipitation defines two seasons, a rainy season (between December and May) and a dry season (between July and November) when total rainfall decreases by half (Bastos, 1972; Falesi, 1986; IDESP, 1983, 1984; Rodrigues, 1986 apud Oliveira, 2002).

The geology of the region is represented by two geological deposits according to Oliveira (2002). The Barreiras Group (Plio-Pleistocene age) consists of continental siliciclastic deposits, poorly selected. The Holocene sedimentary deposits are represented by recent alluvial deposits consisting of gravels, unconsolidated sands and clays (Oliveira, 2002).

However, there is an ancient sedimentary deposit composed of organic-clay sediments, with organic matter debris and associated vegetation remains (branches, leaves and roots). The sedimentary deposit was probably exposed by present erosional coastal processes and is currently being re-colonized by herbaceous plants.

The regional vegetation was composed mainly of rain forest, but it is currently very impacted by human activities, being replaced by secondary forests, while the alluvial forests are only observed close to the rivers (Brasil, 1974 apud Oliveira, 2002). Locally, through field work, stem and root remains of trees were observed in life position of the flooded plain, as genus Pterocarpus and Mauritia flexuosa (buriti palm), as well as the mangrove genera Rhizophora and Avicennia.

\section{MATERIAL AND METHODS}

\section{Core sampling and ${ }^{14} \mathrm{C}$ dating}

The five sediment cores (IT1, IT2, IT3, IT4 and IT5) were taken from organic-clay sedimentary deposits located in the intertidal zone at Itupanema Beach ( $01^{\circ} 31^{\prime} 03$ ' $\left.\mathrm{S} / 48^{\circ} 43^{\prime} 27^{\prime \prime} \mathrm{W}\right)$, using a mud sampler, in December 2004. The samples were collected on a transect directed parallel to the present shoreline. The sediment cores were 42, 20, 36, 42 and $44 \mathrm{~cm}$ long, respectively. The distances between cores were: IT1-IT2 $=7.5$ $\mathrm{m}$; IT2-IT3 $=15 \mathrm{~m}$; IT3-IT4 and IT5 $=1.5 \mathrm{~m}$. The description of sediments was based on texture, structure and consistency (Lemos \& Santos, 1996) and color (Munsell, 1975).

Two sedimentary samples (40-42 cm/IT1) and $(20-22 \mathrm{~cm} /$ IT1) were taken for ${ }^{14} \mathrm{C}$ dating by the accelerator mass spectrometry method (AMS) at Beta Analytic Inc, Miami, U.S.A. ${ }^{14} \mathrm{C}$ dating provides time control on sediment deposits accumulated (Table 1).

\section{Organic matter contents}

The cores were sectioned at $5-\mathrm{cm}$ intervals. The 35 subsamples were analyzed at the Laboratório de Solos e Sedimentos of Museu Paraense Emílio Goeldi and organic matter content was determined according to Walkley-Black (1934) modified method by Jackson (1982 in EMBRAPA, 1997). 


\section{Diatom analysis}

The diatom analyses utilized 40 subsamples of $2 \mathrm{~cm}^{3}$, taken at $3-\mathrm{cm}$ intervals, and were processed according Florin s/d apud Moro \& Santi (1999). Three permanent slides were mounted for each sample using Canada Balsam (Index $\mathrm{H}=1.54)$. AZEISS light microscope (1,000X magnification) was utilized for the identification and the quantification of the diatom species. The scanning electron micrographs that composed the plate were then taken using a ZEISS Scanning
Electron Microscope (SEM), LEO 1450 VP model, at the Laboratório de Microscopia Eletrônica de Varredura of Museu Paraense Emílio Goeldi.

The relative abundance was calculated on total diatom sums of 300 valves per level for each core. The identification of the diatoms was based on the taxonomy studies of Hendey (1964), Patrick \& Reimer (1966), Krammer \& Lange-Bertalot (1991) and Metzeltin \& Lange-Bertalot (1998). The classification system of the species was based on Round et

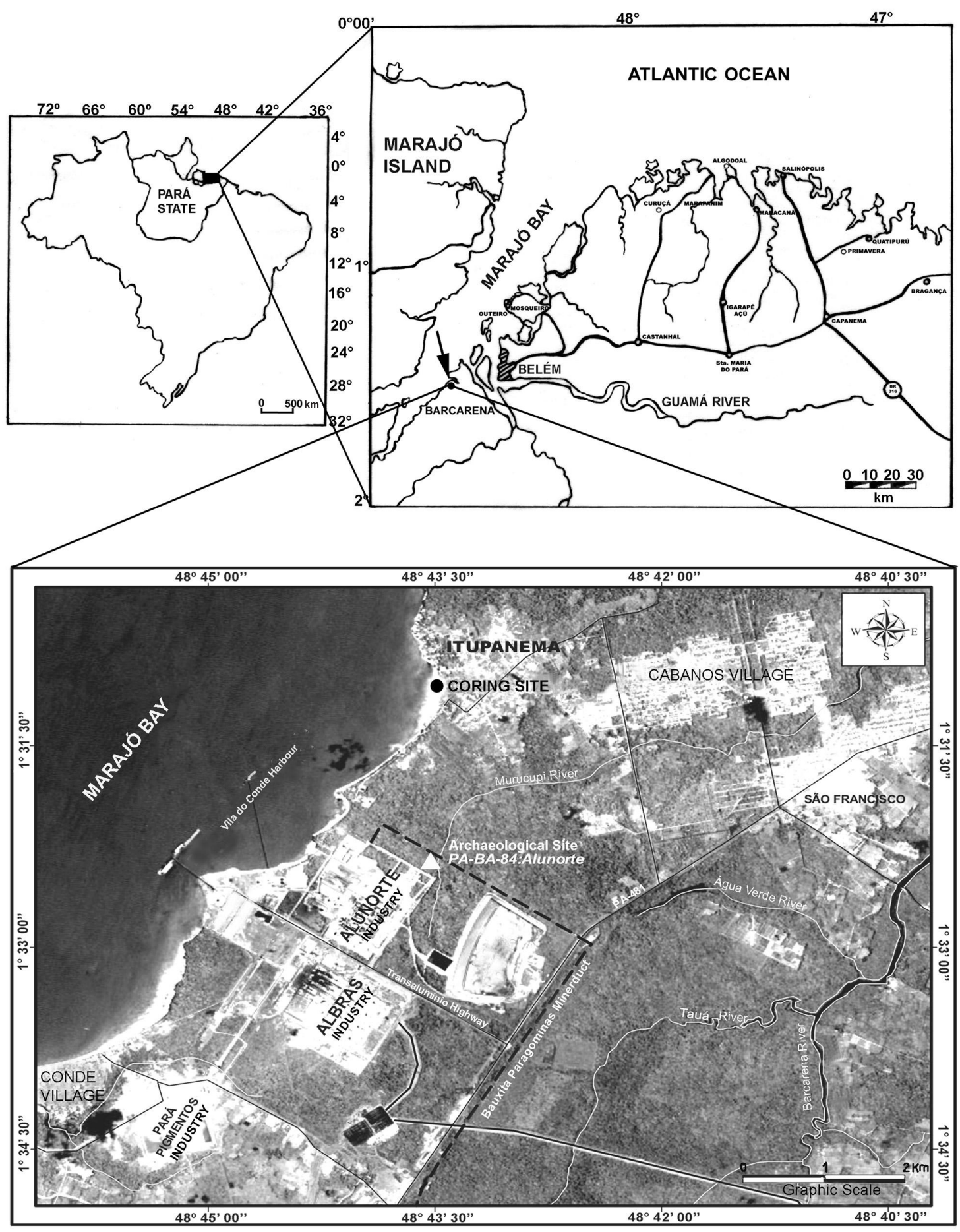

Figure 1. Location of Itupanema Beach, Pará State (indicated by arrow). The coring station is indicated with a solid dot (modified from Ribeiro et al., 2007). 
al. (1990). A table containing information about diatom species ecology was constructed. The slides were deposited in diatom reference collection of the Laboratório de Palinologia e Paleoecologia da Amazônia (LAPPAM), Coordenação de Ciências da Terra e Ecologia/Museu Paraense Emílio Goeldi.

The diatom relative abundance data were used to generate diatom diagrams for each core analyzed, using EXCEL for Windows software. These data included the group of most abundant species, with relative abundance $>5 \%$ in at least two samples, excluding the rare species $(<5 \%)$. The local biostratigraphic ecozones in the cores of Itupanema Beach were established utilizing the ordination technique correspondence analysis for species that showed relative abundances $>5 \%$ in at least two samples, excluding the rare species $(<5 \%)$, performed by PAST version 1.4 software (Hammer et al., 2001).

The reconstructions of both paleoecological and paleohydrological history of Itupanema Beach during the last millennium were based on the diatom diagrams, organic matter content, sedimentary texture and ${ }^{14} \mathrm{C}$ dating. These data were then correlated to additional data from the modern distribution of the diatom assemblages and the association with the sedimentary texture on the surface (Ribeiro et al., 2008).

\section{RESULTS}

\section{The transfer of Fragilaria crassa D. Metzeltin \& H. Lange- Bertalot to the genus Staurosirella Williams \& Round (Bacillariophyceae)}

Staurosirella crassa (D. Metzeltin \& H. Lange-Bertalot) Ribeiro \& Torgan nov.comb.

Basionym. Fragilaria crassa D. Metzeltin \& H. LangeBertalot, Iconographia Diatomologica, Annotated Diatom Micrographs, v. 5, p. 89, fig. 1:20-23; fig. 2: 1. 1998.

Synonym. Staurosira crassa (D. Metzeltin \& H. Lange Bertalot) D. Metzeltin, H. Lange-Bertalot \& F. GarcíaRodríguez, Iconographia Diatomologica, Annotated Diatom Micrographs, v. 15, p. 270, fig. 37. 2005.

Observations. Fragilaria crassa was described by Metzeltin \& Lange-Bertalot (1998) from Amazon, Brazil (at sediment 11,000 yr BP). Morphological features such as striae composed of slit-like areolae oriented parallel to the apical axis of the valve is significant enough for its transfer to the genus Staurosirella Williams \& Round emend. Morales (Morales \& Manoylov, 2006a, b).

\section{Sedimentary sequences}

The sedimentary sequences are shown in Figure 2. The textural variation observed on the sediments indicated that core IT1 was the most diversified among the cores analyzed, because it showed five sedimentary strata, while core IT2 showed a single stratum composed of sand-clay sediments with organic rich material and plant remains. Cores IT3, IT4 and IT5 showed very similar texture, being composed of sandy sediments with a little organic material and a few plant remains on the bottom, where organic matter content increased towards the top.

\section{Diatom analysis}

The diatom analysis of the five cores revealed fifty-eight diatom species. The composition of the diatom species along all cores was the same, although relative abundance values were different. The planktonic species Aulacoseira granulata (Ehrenberg) Simonsen, Actinocyclus normanii (Gregory) Hustedt, Cyclotella meneghiniana Kützing, Polymyxus coronalis L. W. Bailey and Thalassiosira sp. and benthic diatoms Staurosirella crassa (Metzeltin \& Lange-Bertalot) Ribeiro \& Torgan nov. comb., S. pinnata (Ehrenberg) Williams $\&$ Round and Staurosira obtusa (Hustedt) Garcia were the most abundant species in this study (Figure 3). The information about species ecology is shown in Table 2.

The first two components of a CA ordination of species abundance and samples explained $63.01 \%$ of variance and expressed changes in the environment during the last millennium (Table 3). The first axis accounts for $39.97 \%$ differentiated lower ecozones (intervals located on the right) from the intermediate and upper ecozones (located in the center and on the left). Thus, there was a gradient of sandy to clay-organic sediments (Figure 4), which also distinguished planktonic diatoms associated with organic-clay ecozones from benthic diatoms (S. crassa and S. obtusa) associated with sandy ecozones.

The second axis accounts for $23.04 \%$ of variance and

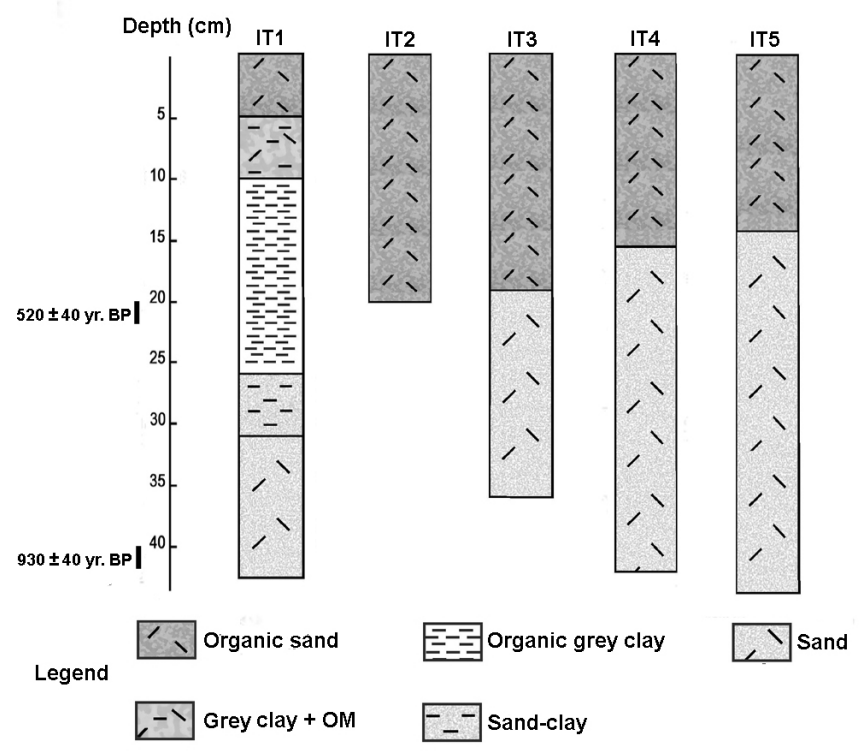

Figure 2. Sedimentary sequences of cores IT1, IT2, IT3, IT4 and IT5, with ${ }^{14} \mathrm{C}$ dating.

Table 1. Sedimentary samples taken of core IT1 for ${ }^{14} \mathrm{C}$ dating, interval sample, sedimentary texture and radiocarbon dates (AMS).

\begin{tabular}{cccc}
\hline Lab number & Depth interval $(\mathbf{c m})$ & Sedim entary texture & ${ }^{14} \mathbf{C}$ yr BP \\
\hline Beta -217591 & $20-22$ & clay with abundant plant remains, branches and rootlets & $930 \pm 40$ \\
\hline Beta -217590 & $40-42$ & sandy with a few plant remains & $520 \pm 40$ \\
\hline
\end{tabular}


showed that the most abundant benthic/epiphytic species including Carpatogramma, Encyonema silesiacum, Frustulia rhomboides, Gomphonema parvulum (Kützing) Kützing, Gomphonema sp. 3, Planothidium lanceolatum, Stauroneis sp. 2, S. pinnata were present on the surface samples of cores, which were differentiated from other samples (Figure 4).

\section{Diatom records from Itupanema Beach}

Itupanema Core IT1. The diatom assemblage was represented by 29 benthic species and 13 planktonic species. Based on diatom analysis and textural related variations, it was possible to establish three ecozones (Figure 5).

The lower ecozone $1(42-26 \mathrm{~cm})$ was dated at the base at $930 \pm 40$ yr BP (Beta 217590), being composed of sandy and grey sand-clay (3/10Y) sediments and low organic matter, with a few plant remains. This ecozone was dominated by both benthic diatoms, Staurosira obtusa and Staurosirella pinnata. However, the planktonic diatom Polymyxus coronalis reached a very high relative abundance at the middle of this zone.

The intermediate ecozone $2(26-10 \mathrm{~cm})$ is composed of grey organic clay $(3 / 10 \mathrm{Y})$ sediments, rich in organic matter, abundant plant remains, branches and rootlets, age $520 \pm 40$ yr BP (Beta 217591). The sediments comprised thin particles (clay), where the sedimentary deposit consisted of a 16-cmthick layer, with a mixture of fine sand at the base and only clay material in the last $12 \mathrm{~cm}$. The diatom composition was the same as the subjacent layer, but the abundance of benthic diatoms was reduced with this ecozone being dominated by the planktonic diatoms Thalassiosira sp., Aulacoseira granulata and Actinocyclus normanii.
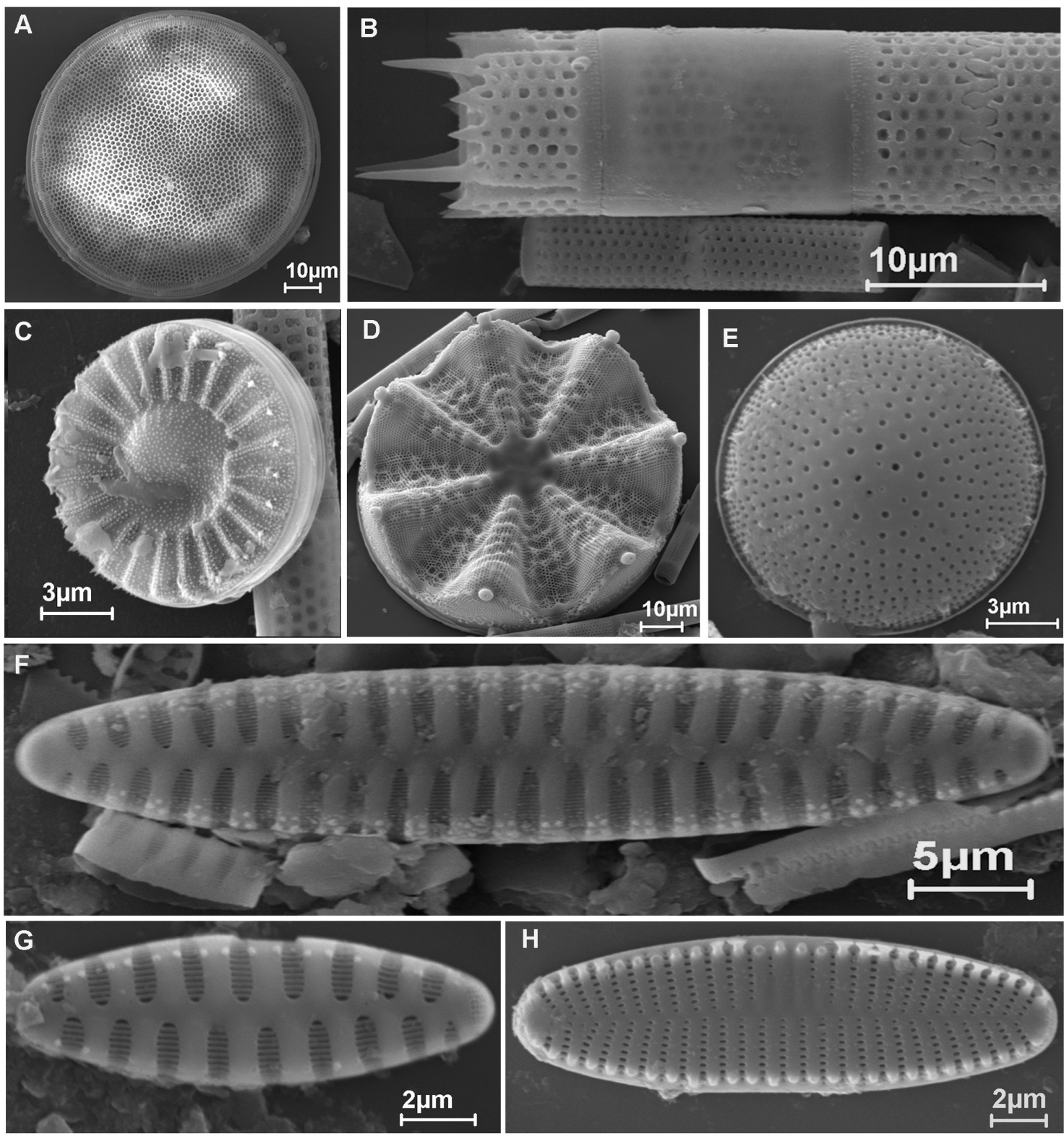

Figure 3. Diatom species most abundant in Itupanema Beach cores. A-E, planktonic diatoms: A, Actinocyclus normanii; B, Aulacoseira granulata; C, Cyclotella meneghiniana; D, Polymyxus coronalis; E, Thalassiosira sp. F-H, benthic diatoms: F, Staurosirella crassa; G, Staurosirella pinnata; $\mathbf{H}$, Staurosira obtusa. 
Table 2. Ecology of most abundant diatom species of the sediments at Itupanema Beach.

\begin{tabular}{|c|c|c|}
\hline Species & Ecology & Reference \\
\hline Aulacoseira granulata & $\begin{array}{l}\text { Freshwater to brackish water, mesosaprobic, alkaliphilic, eutrophic, } \\
\text { planktonic }\end{array}$ & Moro \& Fürstenberger (1997) \\
\hline Actinocyclus normanii & Mesohalobous, indifferent $\mathrm{pH}$, planktonic & Moro \& Fürstenberger (1997) \\
\hline Cyclotella meneghiniana & Freshwater to oligohalobous, alfa-mesosaprobic, alkaliphilic, planktonic & Moro \& Fürstenberger (1997) \\
\hline Fragilaria crassa & Freshwater, epipsammic & Metzeltin \& Lange-Bertalot (1998) \\
\hline Polymyxus coronalis & $\begin{array}{l}\text { Mesohalobous, planktonic, typic al of Amazon estuary, present actually in } \\
\text { phytoplankton of the study area }\end{array}$ & $\begin{array}{l}\text { Moreira-Filho et al. (1974) } \\
\text { Paiva et al. (2006) } \\
\text { El Robrini et al. (2006) }\end{array}$ \\
\hline Thalassiosira sp. & Predominantly marine planktonic genus, several species in freshwater & $\begin{array}{l}\text { Aké-Castillo et al. (1999) } \\
\text { Torgan \& Santos (2006) }\end{array}$ \\
\hline Staurosira obtus a & Estuarine sandy beach, epipsammic & Garcia (2006) \\
\hline Staurosirella pinnata & Freshwater, indifferent salinity, oligosaprobic, eutrophic, epipsammic & Round et al. (1990) \\
\hline
\end{tabular}

Table 3. Eigenvalues and variance explained by correspondence analysis of the diatom species of cores IT1, IT2, IT3, IT4 and IT5.

\begin{tabular}{ccc}
\hline Axes (CA) & Eingenvalue & Variance explained (\%) \\
\hline Axis 1 & 0.43012 & 39.97 \\
Axis 2 & 0.24794 & 23.04 \\
Axis 3 & 0.103443 & 9.6125 \\
Axis 4 & 0.070394 & 6.5414 \\
\hline
\end{tabular}

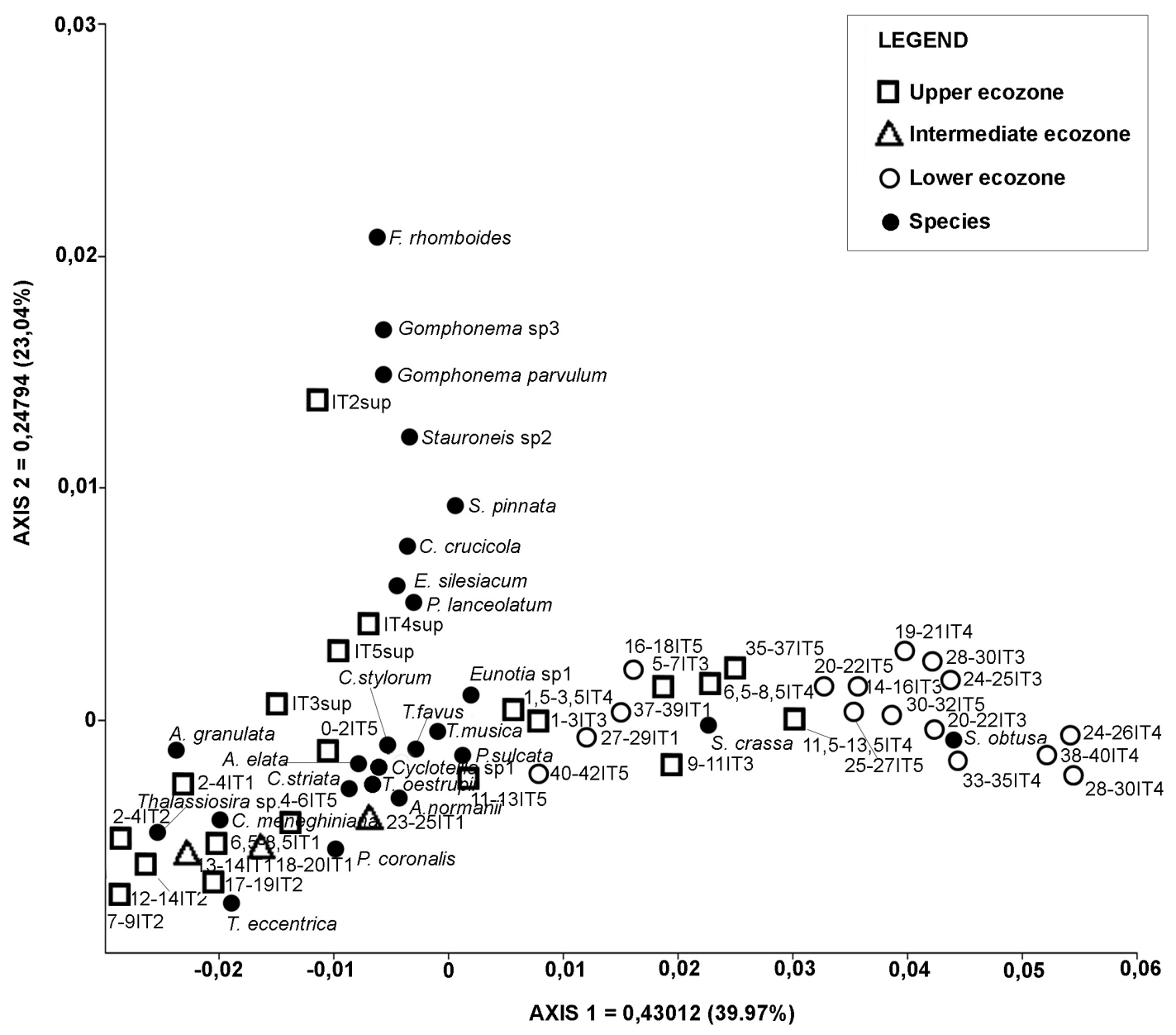

Figure 4. Correspondence analysis ordination of diatom species and sampling intervals of cores IT1, IT2, IT3, IT4 and IT5. 
The upper ecozone $3(10-0 \mathrm{~cm})$ displayed grey sand-clay $(3 /$ $\mathrm{N})$ sediments, rich in organic matter, with abundant plant remains, also occurring both arboreal vegetation remains and palm remains in life position on the surface, indicating that the sediment age is certainly much younger than $520 \pm 40 \mathrm{yr}$ BP. The diatom data showed that this zone was still dominated by Thalassiosira sp. and $A$. granulata, but the benthic diatom $S$. pinnata increased strongly towards the top, in contrast to the relative abundance values observed for other benthic taxa.

Itupanema Core IT2. Core IT2 showed a unique sedimentary stratum composed of grey organic sand-clay (3/10Y) sediment $(20 \mathrm{~cm})$, with abundant plant remains and correlated with the upper ecozone 3 of the IT 1 core. The diatom assemblage was composed of 35 benthic species and 14 planktonic species (Figure 6).

The ecozone 3 was dominated by the planktonic species Thalassiosira sp., A. granulata and C. meneghiniana. Otherwise, A. normanii and Polymyxus coronalis were better represented at the base of ecozone. However, the benthic diatom S. pinnata increased towards the top of the core and reached high values on the surface.

Itupanema Cores IT3, IT4 and IT5. Cores IT3, IT4 and IT5 showed 20, 22 and 26 benthic species and 13, 10 and 10 planktonic species, respectively. The diatoms were absent between 35 and $33 \mathrm{~cm}$ of core IT3. Thus, the three cores were very similar in sedimentary texture and diatom assemblages, where they were analyzed together. The diatom analysis related to organic matter contents showed the existence of two ecozones.

The lower ecozones 1 (36-18 cm/IT3), (42-15.5 cm/IT4) and (44-14 cm/IT5) were composed predominantly of sandy (5/10Y) sediments and low organic matter and corresponded to the lower ecozone 1 in IT1 (Figures 7-9). The relative abundance of the benthic species showed the highest values for S. obtusa and S. crassa. The benthic diatoms dominated the basal ecozones of all cores, in terms of species richness. However, in IT5, at a depth of $42-40 \mathrm{~cm}$, the planktonic species reached $50 \%$ of relative abundance, being represented by Thalassiosira sp., A. granulata, C. striata and A. normanii.

The upper ecozones 3 (18-0 cm/IT3), (15/5-0 cm/IT4) and (14-0 cm/IT5) were composed of organic sand $(6 / 10 \mathrm{Y})$ sediments rich in organic matter and plant remains, corresponding to upper ecozone 3 in IT1 and the unique ecozone in IT2. In these zones, benthic diatoms decreased towards the surface, and the planktonic species Thalassiosira sp. and A. granulata were dominant. The diatom $A$. granulata showed a progressive increase in abundance, reaching the highest values on the surface of the three cores. Thalassiosira sp. had the same abundance pattern, but its numbers were reduced at the surface. The benthic species $S$.

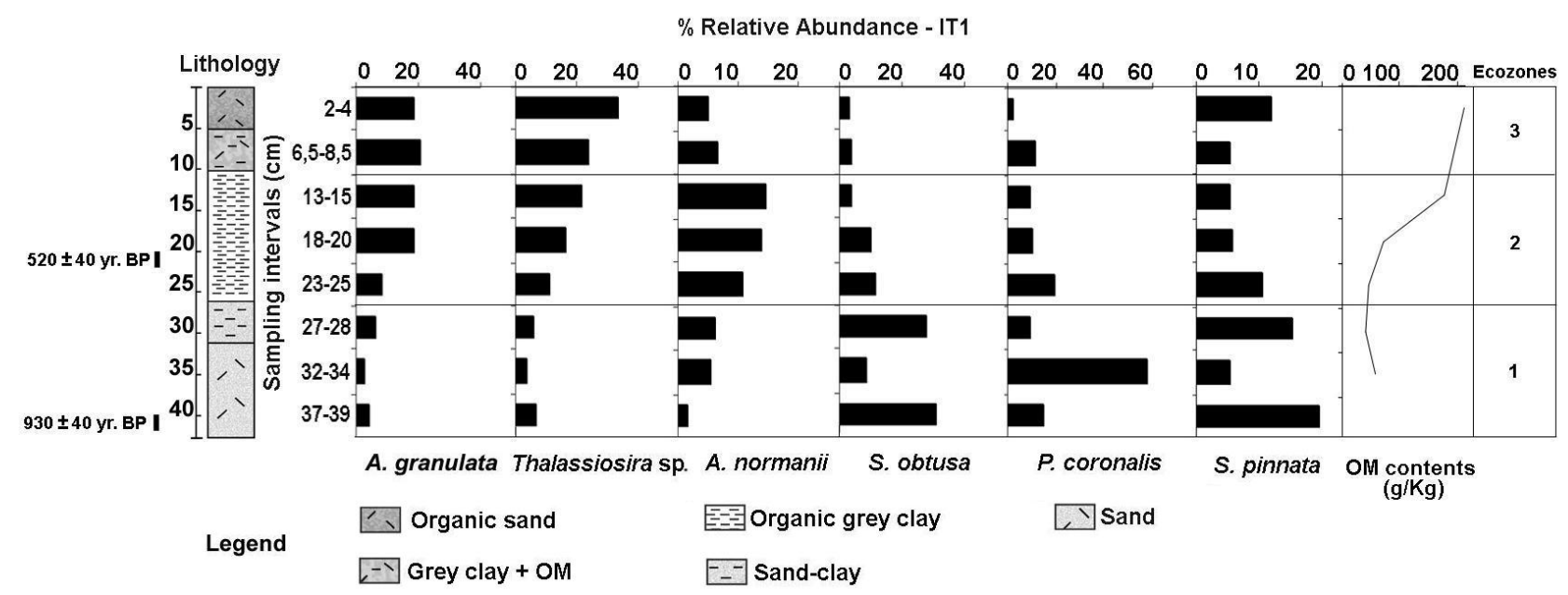

Figure 5. Lithology, OM contents and distribution of most abundant diatom species of core IT1.

$\%$ Relative Abundance - IT2

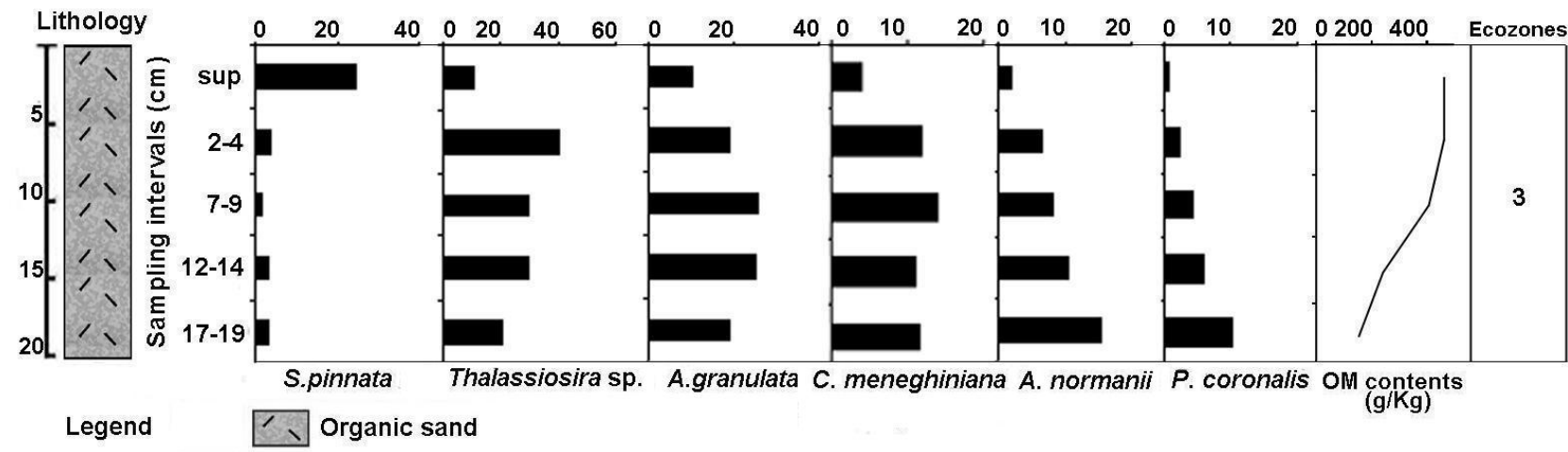

Figure 6. Lithology, OM contents and distribution of most abundant diatom species of core IT2. 


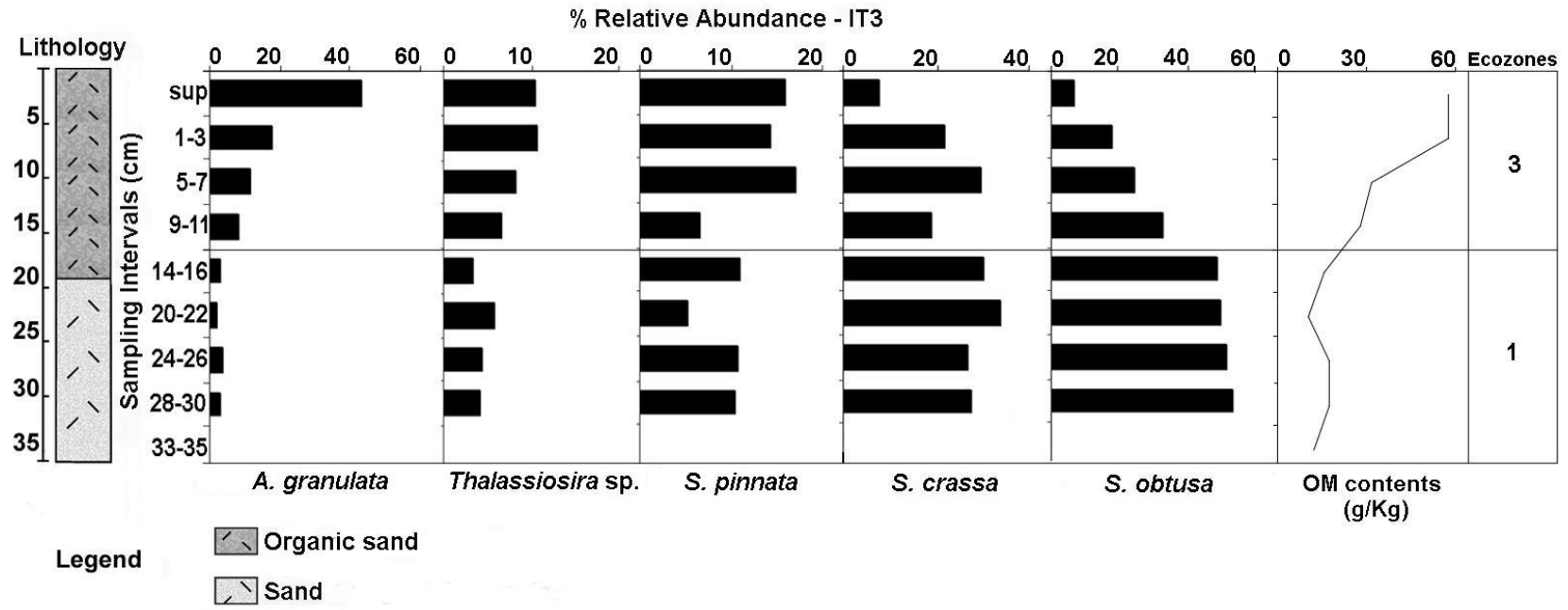

Figure 7. Lithology, OM contents and distribution most abundant of diatom species of core IT3.

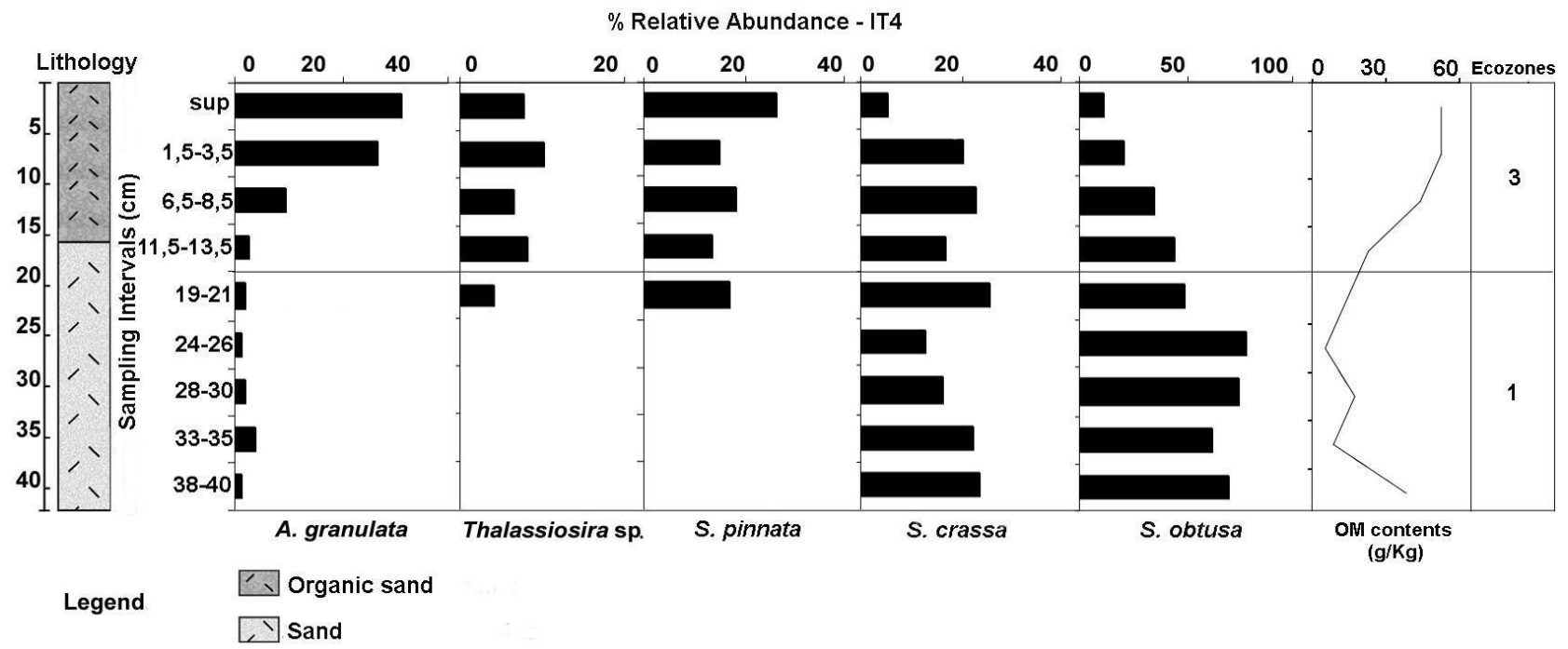

Figure 8. Lithology, OM contents and distribution of most abundant diatom species of core IT4.

$\%$ Relative Abundance - IT5

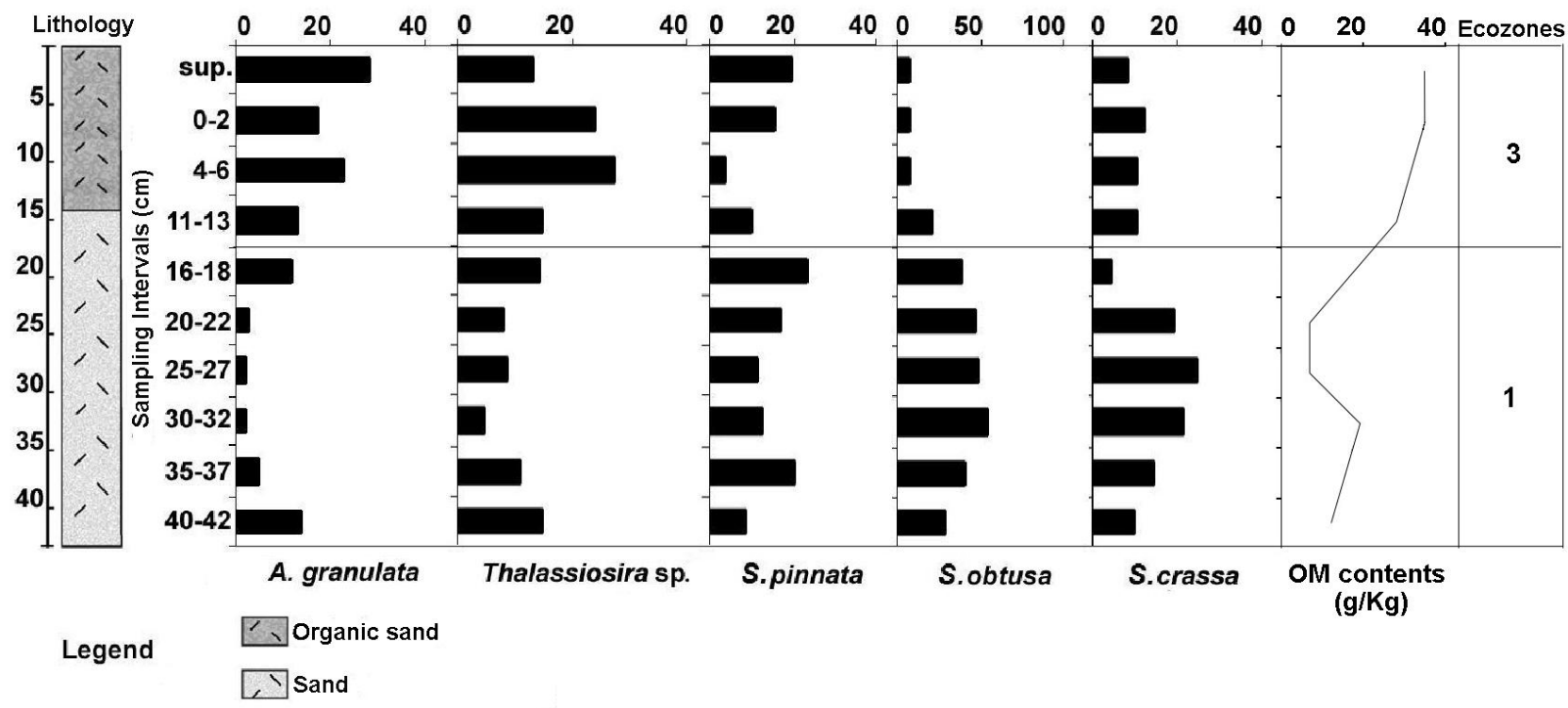

Figure 9. Lithology, OM contents and distribution of most abundant diatom species of core IT5. 
pinnata showed large fluctuations in terms of relative abundance along the cores.

\section{Organic matter content}

Itupanema Core IT1. Low OM contents were observed in the sandy lower ecozone 1 . In the intermediate ecozone $2, \mathrm{OM}$ contents increased abruptly. The upper ecozone 3 showed the highest values of OM contents observed (Figure 5).

Itupanema Core IT2. The OM contents increased strongly along core IT2, reaching very high values at the top. Core IT2 showed the highest OM contents $(464.58 \mathrm{~g} / \mathrm{kg})$ among all cores, which represented twice the $\mathrm{OM}$ values determined in IT1 $(213.39 \mathrm{~g} / \mathrm{kg})$ and approximately nine times the OM values found in IT3 $(57.72 \mathrm{~g} / \mathrm{kg})$, IT4 $(52.47 \mathrm{~g} / \mathrm{kg})$ and IT5 $(34.98 \mathrm{~g} / \mathrm{kg}$ ) cores (Figure 6).

Itupanema Cores IT3, IT4 and IT5. Cores IT3, IT4 and IT5 displayed similar OM contents along the sedimentary strata. The lower ecozones 1 showed very low OM contents. These $\mathrm{OM}$ values increased slightly along the cores, but low $\mathrm{OM}$ values were observed at the top. The higher values at the top of cores IT3, IT4 and IT5 were lower than those of the lower ecozone of core IT1. Core IT5 had the lowest OM contents along the sedimentary strata among all the cores (Figures 7-9).

\section{DISCUSSION}

\section{Modern distribution of diatoms at Itupanema Beach}

The planktonic diatoms are supplanted by benthic forms in number of species and relative abundance on the surface sediments of the Itupanema Beach, indicating that hydrological conditions were unfavorable for sedimentation of the planktonic diatoms from the water column (Ribeiro et al., 2008). However, the planktonic diatoms were more abundant in clay sediments, in the calmer sedimentation conditions. Otherwise, the benthic/epiphytic species were more numerically important, when attached to sand and claysand sediments, indicating more energy from waves and tides, under erosive conditions (Ribeiro et al., 2008).

Ribeiro et al. (2008) reported that the autochthonous community, represented by benthic/epiphytic species, occupied several substrates, from sandy to clay sediments, in addition to herbaceous vegetation at the sampling area. The allochthonous community, represented by planktonic species, was associated with clay sediments, as they represent good sedimentation conditions, preserving the frustules that due to the higher density of vegetation would be less subject to the both abrasion and dissolution processes.

Thus, the data of the modern distribution of the diatom species appear to be reliable for paleoenvironmental and paleohydrological reconstructions of Itupanema Beach during the last millennium.

\section{Paleoenvironmental and paleohydrodynamic reconstructions}

The paleoecological and paleohydrological history of Itupanema Beach during the last millennium was shown along three ecozones that were delimited based on the diatom diagram associated with organic matter content, sedimentary texture and ${ }^{14} \mathrm{C}$ dating.

Ecozone $1\left(930 \pm 40\right.$ yr ${ }^{14} \mathrm{C}$ BP - Beta 217590). During this period, sedimentation occurred in a shallow estuarine environment, with strong hydrodynamic energy. The sandy plain was subject to an intense erosive process, with substratum exposed to wave and tide actions, therefore unfavorable for colonization by herbaceous plants, as shown by the low OM contents observed in the lower ecozones of cores IT1, IT3, IT4 and IT5. This environmental condition was corroborated by the presence of the diatom species Staurosira obtusa and Staurosirella crassa, which dominated the diatom assemblage and showed ecological affinity to the epipsammic habitat (Table 2). Garcia (2006) also reported S. obtusa as having an epipsammic habitat in Laranjal Bay in South Brazil.

The low richness of planktonic diatom species and the low abundance was also observed in the sandy zones. This is probably due to the low resistance of the diatom valves to abrasion and dissolution with more hydrological energy. The absence of diatoms was observed in core bases of El Caimito Lake, at Chocó, Pacific coast of Colombia, due a high porosity of sandy deposit preventing the algal preservation (Vélez et al., 2001). The same situation was also observed in a core collected at El Piñal Lake, northeast Colombia, with high sand content and low organic content, attributed to a high energy depositional environment (Vélez et al., 2005). Garcia (1996) also showed that the sampling stations with the lowest numbers of organisms were those located near the zone with substrate disturbance by wave action, and therefore, with more depositional energy.

The sandy ecozone IT1 showed a probably short event situated at $34-32 \mathrm{~cm}$ depth, representing a calm sedimentary environment, with minimum influence of waves and tides, evidenced by elevated abundance of the planktonic species Polymyxus coronalis (57.67\%). This species is a typical component of phytoplankton in the estuarine region of the Amazon River (Moreira-Filho et al., 1974), and occurs with more than 50\% relative abundance in microphytoplankton of Guajará Bay and the mouth of the Guamá River along the whole year (Paiva et al., 2006). Therefore, its abundance decreases (30$35 \%)$ in the dry season at the mouth of the Pará River, which flows into Itupanema Beach (El - Robrini et al., 2006).

Thus, only a depositional environment sufficiently calm could show conditions for the preservation of the large Polymyxus coronalis diatom (44 to $128 \mu \mathrm{m}$ diameter), according to Navarro \& Peribonio (1993), and with large available surface to abrasion and dissolution processes. In addition, this species showed low representation in recent sediments of Itupanema Beach (Ribeiro et al., 2008).

Ecozone $2\left(520 \pm 40\right.$ years ${ }^{14} \mathrm{C}$ BP - Beta 217591). The organic grey clay sediments occurred at ecozone 2 which was present only in the IT1 core. The diatom assemblage in this zone was dominated by planktonic species A. normanii, A. granulata and Thalassiosira sp., indicating a calmer environment, with deeper water and relatively low hydrodynamic energy, which facilitated the preservation of these organisms. This indicated a local change of sedimentation environment in a probably protected area, which favored the intense sedimentation of clay material associated with higher OM contents, where plant remains (branches, roots and leaves) were associated with palynological data, indicating a probable mangrove forest associated with alluvial palm forest (Senna et al., 2007). 
Ribeiro et al. (2008) reported that at surface sediments of Itupanema Beach, A. granulata and Thalassiosira sp. were associated with clay sediments, reaching higher values of relative abundance, while $A$. normanii was associated with clay-sand sediments and integrated the group of rare species.

In Iguape Bay, Bahia State, Brazil, Gomes et al. (2003) analyzed the sediments of a core and characterized this sedimentation environment by the presence of clay sediments with small plant fragments, and good preservation of diatom valves, where the ratio of planktonic:benthic diatoms was higher, indicating low hydrodynamic energy.

Palynological studies conducted at the Pará Coastal Zone showed a decrease in the frequency of inundation and, consequently, a calmer sedimentary environment, associated with a period of relatively lower sea level and dry season with less rainfall for the same time period. The new environmental conditions were associated with sea-level regression in northeastern Pará (Behling et al., 2001, Cohen et al., 2005b) and are temporally correlated with the so-called Little Ice Age (Cohen et al.,2005a).

Ecozone 3 (younger than $520 \pm 40$ yr BP). In this period, a new change was detected in the sedimentary record, with higher hydrodynamic energy than that of ecozone 2 , with shallow water conditions. However, the hydrodynamic energy was less than that in ecozone 1 and showed a new erosive period on Itupanema Beach. In this ecozone, the planktonic species still showed high abundance. The diatoms $A$. granulata and Thalassiosira sp. prevailed with highest values of relative abundance in both organic strata and surface of cores, while other diatom species showed abrupt numerical reductions. The sediments had higher organic and plant remain contents, also higher OM contents, probably because of the decomposition of herbaceous vegetation, which still occurs currently on the beach.

The pollen analysis on the same sediments showed the predominance of palm pollen (Mauritia/Mauritiella type) with the highest values of relative abundance, associated with herbaceous pollen of Gramineae and Cyperaceae and Rhizophora pollen (Senna et al., 2007). Therefore, the pollen data showed a local fluvial-estuarine environment with floodplain ecosystem and mangrove patches, with predominance of palm trees very similar to the current one. Thus, these data confirm that the sediment age of ecozone 3 is much younger than $520 \pm 40 \mathrm{yr} \mathrm{BP}$.

The aquatic herbaceous vegetation probably played a very important role in reducing both wave energy and tidal current velocities at Itupanema Beach and contributed to the retention of muddy sediments and consequently preserving planktonic species (Ribeiro et al., 2008).

The relative abundance of $A$. granulata reached values close to $10 \%$ in the phytoplankton collected at the Pará River (El-Robrini et al., 2006), but in upper ecozones from sediments of Itupanema Beach, the relative abundance of $A$. granulata reached higher values. These results are explained by the heavily silicified frustules of this genus (Bradbury, 1975 in Wolin \& Duthie, 1999), resistant to abrasion in a environment with high energy on the surface, in contrast to other fragile planktonic species (e.g., Polymyxus coronalis and $A$. normanii).
The presence of $A$. granulata in organic sediments indicated a turbulent aquatic environment, where the genus shows high sinking rates, and thus, its ecology requires turbulence to maintain its presence in the water column (Bradbury, 1975 in Wolin \& Duthie, 1999).

Vélez \& Hooghienmstra (2005) characterized A. granulata as a species living in both fresh and brackish water, in mixed water and moderately eutrophic and alkaline water in a study on Lake El Piñal, northeastern Colombia. In the same study, A. gralulata reached higher values of abundance in samples collected from roots and sediments in the littoral zone $(36.17 \%)$ compared to plankton $(23.85 \%)$ and to surface sediments of the bottom of the lake $(22 / 89 \%)$.

The taxon Thalassiosira sp. was quite frequent and abundant, with presence in all ecozones and cores, with similar distribution compared to A. granulata. However, there is no ecological information about this species, where its presence in works on Brazilian estuaries has not yet been reported. Thus, the species needs detailed studies about its taxonomy, morphology, ecology and distribution.

In the upper ecozone 3 , only $S$. pinnata was the benthic species that reached higher numerical values, mainly in surface sediments. Its presence in surface sediments was also demonstrated in several studies (Bennion, 1995; Sylvestre et al., 2001; Gomes et al., 2005). The surface sediments of Itupanema Beach showed S. pinnata as the most abundant species in sandy and clay-sand sediments, being associated principally with sandy sediment (Ribeiro et al., 2008).

Gomes et al. (2005) analyzed surface sediments from Lake Boqueirão, Rio Grande do Norte State, northeast Brazil, where $S$. pinnata was the more abundant species (41.6\%), being considered a typical littoral species, living on the bank of shallow lakes, generally associated with periphyton, but in this case its presence was associated with macrophyte banks.

In surface sediments from hypersaline coastal lagoon Araruama, located in Rio de Janeiro, Brazil, Sylvestre et al. (2001) observed different areas of the lagoon with a specific diatom assemblage composed of two dominant taxa, Staurosira elliptica (Schumann) Williams \& Round and Staurosirella pinnata. In Araruama Lagoon, S. elliptica is epipsammic, forming ribbon-shaped colonies and $S$. pinnata is a tychoplanktonic species, generally living in fresh to oligosaline water (0-5\%). The dominance of this species in these lagoon areas was related to fluctuations in water level, where these areas are influenced by water inputs from the ocean and from rivers adjacent to the lagoon.

Bennion (1995), also studied surface sediments from shallow, artificial, enriched ponds in southeast England and reported that the diatom assemblages were dominated by Fragilaria spp. (genus split by Williams \& Round, 1987 into several new genera: Fragilariforma, Pseudostaurosira, Punctastriata, Staurosira and Staurosirella), commonly associated with a benthic habitat. Therefore, a possible explanation for its dominance is that the very shallow waters, both in the littoral zone and even in the deep zone, provide a considerable area for colonization by benthic forms, with much of the bottom sediment lying within the photic zone. 


\section{CONCLUSIONS}

The textural variation observed in the five core sediments demonstrated changes in estuarine hydrodynamics, with strong implications on distribution and relative abundance of both planktonic and benthic diatoms and on vertical and lateral variations of sedimentary environment.

The modern diatom distribution and its association with textural sediments observed in the intertidal zone at Itupanema Beach showed an important role in the paleoecological and paleohydrological reconstruction during the last millennium.

About 900 yr BP, Itupanema Beach showed more hydrodynamic energy than nowadays, originating a shallow sedimentary environment, with sandy sediments under erosive conditions, unfavorable for the colonization of vegetation. Evidence of these environmental conditions was the prevalence of benthic/epipsammic diatoms in the sediments. These conditions persisted for about 400 years. However, a short period of calm sedimentary environment probably occurred, with minimum influence of waves and tides shown by the high abundance of the planktonic species Polymyxus coronalis.

The hydrodynamic conditions changed about $500 \mathrm{yr}$ BP to a deeper and calmer environment, located in a probably protected area, with intense sedimentation of clay particles with abundant plant remains (branches, roots and leaves), forming an organic clay sedimentary deposit, colonized by mangrove forest and alluvial palm forest. These new environmental conditions contributed to the retention of organic muddy sediments and favored the dominance of planktonic diatom species, indicated by the good preservation of these organisms.

Itupanema Beach returned to more agitated and erosive sedimentary conditions, however, with less energy than that in lower ecozones. This new sedimentary environment allowed colonization of aquatic macrophyte vegetation, probably at a younger age than $520 \pm 40 \mathrm{yr}$ BP. These environmental conditions persist on the beach today. The diatom assemblage was dominated by planktonic species, highlighting the strongly silicified diatom species $A$. granulata, associated to Thalassiosira $\mathrm{sp}$.

The Little Ice Age period, evidenced by pollen analysis, showed the need for further research for a possible correlation with the diatom data of Itupanema Beach, to prove if this event can be confirmed for the Continental Estuarine Sector of Pará State.

Taken together, the results show that the changes in the sand/clay ratio of the sedimentary strata influenced the ratio of the benthic/planktonic diatom species, probably caused by local hydrodynamic changes that occurred during the last millennium.

\section{ACKNOWLEDGEMENTS}

The authors thank Regina Célia Tavares Lobato and Rosildo Santos Paiva for providing very useful suggestions which improved the overall quality of the manuscript. Special thanks go to Companhia Vale do Rio Doce for providing financial support for field work and radiocarbon dating. CNPq awarded a scholarship to the first author. The authors also thank Ana Paula Fonseca Tavares de Freitas for English revision. This paper was a contribution to the XII SBPP (Florianópolis, November 02-05th, 2008).

\section{REFERENCES}

Abreu, V. dos S.; Torgan, L.C.; Esteves, I.R.F. \& Kotzran, S.C.B. 1987. Estudo paleogeográfico do Quaternário de Morretes, R.S. Brasil. In: CONGRESSO DA ABEQUA, 1, 1987. Anais, Porto Alegre, p. $177-189$.

Aké -Castillo, J.A.; Hernández-Becerril, D.U. \& Castillo, M.E.M 1999. Species of the genus Thalassiosira (Bacillariophyceae) from the Gulf of Tehuantepec, Mexico. Botanica Marina, 42:487-503.

Alves, M.A.M.S; El-Robrini, M.; Sousa-Filho, P.W.M; Farias, D.R. \& França, C.F. 2005. Morfodinâmica das praias de mesomacromarés da zona costeira do estado do Pará. In: CONGRESSO DA ABEQUA, 10, 2005. CD-ROM de resumos expandidos, Guarapari, UFRJ.

Behling, H.; Cohen, M.C.L. \& Lara, R.J. 2001. Studies on Holocene mangrove ecosystem dynamics of the Bragança Peninsula in northeastern Pará, Brazil. Palaeogeography, Palaeoclimatology, Palaeoecology, 167:225-242.

Bennion, H. 1995. Surface-sediment diatom assemblages in shallow, artificial, enriched ponds, and implications for reconstructing trophic status. Diatom Research, 10(1):1-19.

Callegaro, V.L.M. \& Lobo, E.A. 1990. Distribuição horizontal da comunidade de diatomáceas em turfeiras holocênicas da planície costeira do Rio Grande do Sul, Brasil. Pesquisas, Série Botânica, 2(1):5-22.

Cohen, M.C.L.; Behling, H. \& Lara, R.J. 2005a. Amazonian mangrove dynamics during the last millennium: the relative sea-level and the little Ice Age. Review of Palaeobotany and Palynology, 136:93-108.

Cohen, M.C.L.; Souza Filho, P.W.; Lara, R.L.; Behling, H. \& Angulo, R. 2005b. A model of Holocene mangrove development and relative sea-level changes on the Bragança Peninsula (northern Brazil). Wetlands Ecology and Management, 13:433-443.

Clerot, L.C.P.; Medeanic, S.; Torgan, L.C.; Dillenburg, S.R. \& Tomazelli, L.J. 2003. Evolução de Barreira IV na Região do Cassino, Rio Grande, RS. In: CONGRESSO DA ABEQUA, 9, 2003. Resumos Expandidos, Recife, UFPE, CD-ROM.

Cooper, S.R. 1999. Estuarine paleoenvironmental reconstructions using diatoms. In: E.F. Stoerner, \& J.P. Smol (eds.) The Diatoms: Applications for the environmental and sciences, Cambridge University Press, p. 352-373.

El-Robrini, M.; Melo, N.F.A.C. \& Santos, M.L. 2006. Resultados das análises de qualidade de água, sedimentos de fundo, comunidades aquáticas (plâncton, bentos \& nécton) e bacteriologia no rio Pará, nas imediações do futuro terminal portuário graneleiro de Barcarena (porto de Vila do Conde, Barcarena-PA) (1 $1^{a}$ campanha). Relatório Técnico, Universidade Federal do Pará, Belém, PA, 75 p.

EMBRAPA, 1997. Manual de métodos de análise de solo. 2 ed. Rio de Janeiro, Centro Nacional de Pesquisa de Solos, 212 p.

França, C.F.; Souza Filho, P.W.M. \& El-Robrini, M. 2007. Análise faciológica e estratigráfica da planície costeira de Soure (margem leste da ilha de Marajó-PA), no trecho compreendido entre o canal do Cajuúna e o estuário Paracauari. Acta Amazônica, 37(2):261-268.

Garcia, M. 1996. The distribution of psammic algae on a marine beach at Praia Azul, Brazil. In: INTERNATIONAL DIATOM SYMPOSIUM, 30, 1996. Proceedings, Bristol, p. 183-205.

Garcia, M. 2006. The transfer of Fragilaria obtusa Hustedt to the genus Staurosira Ehrenberg (Bacillariophyceae). Phycological Research, 54(2):87-93.

Gomes, D.F.; Brichta, A.; Silva, E.M. \& Fernandes, L.F. 2003. Diatomáceas como indicadoras de mudanças ambientais da Baía de Iguape, Baixo Paraguaçu (Bahia, Brasil). In: CONGRESSO DA ABEQUA, 9, 2003. Resumos Expandidos, Recife, UFPE, CD-ROM.

Gomes, D.F.; Albuquerque, A.L.S.; Sifeddine, A. \& Turcq, B. 2005. Heterogeneidade espacial da comunidade de diatomáceas nos sedimentos superficiais da lagoa do Boqueirão $(\mathrm{RN})$ como fator de calibração para interpretações paleolimnológicas. In: CONGRESSO DA ABEQUA, 10, 2005. Resumos Expandidos, Guarapari, UFRJ, CD-ROM.

Hammer, Ø.; Harper, D.A.T. \& Ryan, P.D. 2001. PAST: Paleontological Statistics Software Package for Education and Data Analysis. Available at http://palaeo-electronica.org/2001_1/past/ issue1_01.htm; accessed on 17/07/2008. 
Hendey, N.I. 1964. An Introductory Account of the Smaller Algae of British Coastal Waters, Part V: Bacillariophyceae (Diatoms). London, Her Majesty‘s Stationery Office, 317 p.

Ireland, S. 1987. The Holocene sedimentary history of coastal lagoons of Rio de Janeiro State, Brasil. In: M. Tooley \& I. Shennan (eds.) Sea Level Changes, Basil Blackwell, $260 \mathrm{p}$.

Jackson, M.L. 1982. Analisis quimico de suelos. Barcelona, Omega, p. 282-309.

Kasim, M. \& Mukai, H. 2006. Contribution of benthic and epiphytic diatoms to clam and oyster production in the Akkeshi-ko Estuary. Journal of Oceanography, 62:267-281.

Krammer, K. \& Lange-Bertalot, H. 1991. Bacillariophyceae: Centrales, Fragilariaceae, Eunotiaceae. In: Ettl et al. (eds.) Süsswasserflora von Mitteleuropa, Gustav Fischer, v. 2, pt. 3, 576 p.

Lemos, R.C. \& Santos, R.D. 1996. Manual de descrição e coleta de solo no campo. $3^{\mathrm{a}}$ ed. Campinas, Sociedade Brasileira de Ciência do Solo, 83 p.

Medeanic S.; Marques-Toigo, M. \& Toldo Junior, E.E. 2001. The use of fossil algae for palaeoenvironmental reconstruction during the late Holocene in the Maquiné river valley, RS, Brazil. Geociências, 5:168-172.

Medeanic, S. \& Torgan, L.C. 2006. Silicoflagellate records in Holocene lagoon sediments in the south Brazil. In: EUROPEAN PALEOBOTANY-PALYNOLOGY CONFERENCE, 7, 2006. Abstract, Prague, p. 91.

Medeanic, S.; Torgan, L.C.; Clerot, L.C.P. \& Santos, C.B. 2009. Holocene Marine Transgression in the coastal plain of Rio Grande do Sul, Brazil: palynomorph and diatom evidence. Journal of Coastal Research, 25(1):224-233.

Metzeltin, D. \& Lange-Bertalot, H. 1998. Tropical diatoms of the South America I. Iconografia Diatomologica, 5:1-695.

Metzeltin, D.; Lange-Bertalot, H \& García-Rodríguez, F. 2005. Diatoms of Uruguay. Iconographia Diatomologica, 15:1-730.

Mitbavkar, S. \& Anil, A.C. 2002. Diatoms of the microphytobenthic community: population structure in a tropical intertidal sand flat. Marine Biology, 140:41-57.

Morales, E.A. \& Manoylov, K.M. 2006a. Staurosirella incognita Morales et Manoylov sp. nov., a non-spiny species from North America, with an emended description of Staurosirella Williams et Round (Bacillariophyceae). In: INTERNATIONAL DIATOM SYMPOSIUM, 18, 2006. Proceedings, Bristol, p. 325-336.

Morales, E.A. \& Manoylov, K.M. 2006b. Morphological studies on selected taxa in the genus Staurosirella Wiliams et Round (Bacillariophyceae) from rivers in North America. Diatom Research, 21(2):343-364.

Moreira Filho, H.; Valente-Moreira, I.M. \& Trippia-Cecy. I.I. 1974. Diatomáceas do rio Guamá (foz do rio, Belém, Estado do Pará). Leandra, 4-5:123-135.

Moro, R.S. \& Fürstenberger, C.B. 1997. Catálogo dos principais parâmetros ecológicos de diatomáceas não-marinhas. Ponta Grossa, Editora da UEPG, 282 p.

Moro, R.S. \& Santi, V. 1999. Avaliação das técnicas de oxidação comumente empregadas na limpeza de valvas silicosas. Boletim da Sociedade Brasileira de Limnologia, 26:17-25.

Munsell Colors Company. 1975. Munsell Soil Coors Charts. Baltimore, Maryland, USA.

Nascimento, L.R.; Sifeddine, A.; Albuquerque, A.L.S.; Torgan, L.C. \& Gomes, D.F. 2003. Estudo da evolução paleohidrológica do Lago Caçó (MA-Brasil) nos últimos 20.000 anos inferido através das diatomáceas. In: CONGRESSO DAABEQUA, 9, 2003. Resumos Expandidos, Recife, UFPE, CD-ROM.

Navarro, J.N. \& Peribonio, R.G. 1993. A light and scanning electron microscope study of the centric diatom Polymyxus coronalis (Bacillariophyta). European Journal of Phycology, 28:167-172.

Oliveira, R.D. 2002. Zoneamento Agroambiental do Município de Barcarena, Pará. Programa de Pós-Graduação em Agronomia, Faculdade de Ciências Agrárias do Pará, Dissertação de Mestrado, $110 \mathrm{p}$.

Paiva, R.S.; Eskinazi-Leça, E.; Passavante, J.Z.O.; Silva-Cunha, M.G.G \& Melo, N.F.A.C. 2006. Considerações ecológicas sobre o fitoplâncton da Baía do Guajará e foz do rio Guamá (Pará-Brasil).
Boletim do Museu Paraense Emílio Goeldi, Série Ciências Naturais. 2(2):133-146.

Patrick, R. \& Reimer, C.W. 1966. The Diatoms of United States: exclusive of Alaska and Hawaii. Philadelphia, Academy of Natural Sciences, 1(13): 1-688.

Round, F.E.; Crawford, R.M. \& Mann, D.G. 1990. The Diatoms: biology and morphology of the genera. New York, Cambridge University Press, 747 p.

Ribeiro, F.C.P. \& Senna, C.S.F. 2005. O Uso das diatomáceas como bioincadores paleoambientais na costa brasileira. In: CONGRESSO DA ABEQUA, 10, 2005, Resumos Expandidos, Guarapari, UFRJ, CD-ROM.

Ribeiro, F.C.P.; Senna, C.S.F. \& Costa, B.O. 2007. Análise diatomológica e paleoecologia da Praia de Itupanema, Barcarena, Pará. Revista Brasileira de Biociências, 5(supl. 2):78-80.

Ribeiro, F.C.P.; Senna, C.S.F. \& Paiva, R.S. 2005. Análise da riqueza, diversidade e equabilidade da diatomoflórula em sedimentos holocênicos da baía de Marapanim-Pa. In: CONGRESSO NACIONAL DE BOTÂNICA, 56, 2005. Resumos, Curitiba, UFPR, CD-ROM.

Ribeiro, F.C.P.; Senna, C.S.F. \& Paiva, R.S. 2006. Análise diatomológica em sedimentos estuarinos do rio Marapanim/Pará: mudanças paleohidrológicas e paleoambientais nos últimos 7.000 anos. In: CONGRESSO BRASILEIRO DE FICOLOGIA \& SIMPÓSIO LATINO-AMERICANO SOBRE ALGAS NOCIVAS, 11, 2006. Livro de Resumos, Itajaí, p. 54.

Ribeiro, F.C.P.; Senna, C.S.F. \& Torgan, L.C. 2008. Diatomáceas em sedimentos superficiais na planície de maré da praia de Itupanema, Estado do Pará, Amazônia. Rodriguesia, 59(2):309-324.

Saupe, A.C. \& Mosimann, R.M. de S. 2003. Diatomáceas (Bacillariophyta) preservadas nos sedimentos holocênicos da lagoa do Peri, Florianópolis, SC, Brasil. Ínsula, 32:33-61.

Senna, C.S.F. \& Ribeiro, F.C.P. 2005. Análise palinológica e diatomológica em sedimentos holocênicos da baía de Marapanim, estado do Pará. In: CONGRESSO DAABEQUA, 10, 2005, Resumos Expandidos, Guarapari, UFRJ, CD-ROM.

Senna, C.S.F.; Ribeiro, F.C.P.; Costa, B.O.; Rodrigues, L.C.S.; Lopes, P.R.C. \& Alves, M.A.M. 2007. Paleoambientes e ocupação humana pré-histórica do estuário do rio Pará, Amazônia, no último milênio. In: COLACMAR, 12, 2007, Livro de Resumos, Florianópolis, UFSC, p. 343.

Souza Filho, P.W.M. \& El-Robrini, M. 1996. Morfologia, processos de sedimentação e litofácies dos ambientes morfo-sedimentares da planície costeira Bragantina, nordeste do Pará, Brasil. Geonomos, $4(2): 1-16$.

Sylvestre, F.; Beck-Eichler, B.; Duleba, W. \& Debenay, J.P. 2001 Modern benthic diatom distribution in a hypersaline coastal lagoon: the Lagoa de Araruama (RJ), Brazil. Hydrobiologia, 443:213-231.

Torgan, L.C. \& Santos, C.B.dos. 2006. Thalassiosira weissflogii (Coscinodiscophyceae, Bacillariophyta) em ambientes lacustres na planície costeira do sul do Brasil. Iheringia, Série Botânica, 61(1-2):135-138.

Vélez, M.I.; Wille, M.; Hooghiemstra, H.; Metcalfe, S.; Vandenberghe, J. \& Van Der Borg, K. 2001. Late Holocene environmental history of southern Chocó region, Pacific Colombia; sediment, diatom and pollen analysis of core El Caimito. Palaeogeography, Palaeoclimatology, Palaeoecology, 173:197-214.

Vélez, M.I. \& Hooghiemstra, H. 2005. Fossil and modern diatom assemblages from the savanna lake El Piñal, Colombia: an environmental reconstruction. Diatom Research, 20(2):387-407.

Walkley, A. \& Black, I.A. 1934. An examination of the Degtjareff method for determining soil organic matter, and a proposed modification of the chromic acid titration method. Soil Science, 37:29-38.

Wolin, J.A. \& Duthie, H.C. 1999. Diatoms as indicators of water level change in freshwater lakes. In: E.F. Stoerner \& J.P. Smol (eds.) The diatoms: applications for the environmental and sciences, Cambridge University Press, p. 352-373.

Williams, D.M. \& Round, F.E. 1987. Revision of the genus Fragilaria Diatom Research, 2(2):267-288.

Received in January, 2009; accepted in February, 2010. 